\title{
Pleasure and Suffering at Work: Case Study with Employees at the Administrative Section of a Construction Material Company in DF
}

\author{
Carla Sabrina Antloga*, Ana Magnólia Mendes, Marina Maia \\ Institute of Psychology, University of Brasília, Brasília, DF, Brazil
}

\begin{abstract}
This study analyzes the employee experiences of pleasure and suffering at work. It was carried out with an administrative staff of an organization of civil construction material in Distrito Federal. The article considers, at first, a historical frame of the studies of pleasure and suffering at work in order to contextualize the research. The study consisted in performing interviews with four employees part of the ad ministrative staff of the mentioned organization. It uses a qualitative methodology for both the data acquisition and the data analysis. In order to collect enough data to perform the study, a semi-structured interview was used which was then taped and further transcribed. To analyze the data we submitted then to a content thematic categorical analysis. The results pointed to a prevail of suffering at work, due to the relationship with the bosses, working hours, overload and the need of enjoying the job. On the final considerations, it is discussed the implications of a stressful work as far as the emp loyee's well being and productivity is concerned.
\end{abstract}

Keywords Pleasure-suffering at Work, Administrative Department

\section{Introduction}

This artic le aims to report the case study using the reality of a civil construction company in Distrito Federal. The approach of psychodymanics of work was taken as reference[1-2] and that encompasses the dynamic of pleasure and suffering of the worker provided his/her organization at work.

With the objective to structure this investigation, the following questions are placed: how is the organization of work in the administrative department of the company? At work, do the employees experience more pleasure or suffering? If there is suffering, how do the employees deal with it?

Given the research questions, the general objective is to analyze the relationships between the organization of the collaborators' work and their experiences with pleasure and suffering at work. Specifically, it is intended to analyze detailedly the organization of work and the relationship with the history of the organization, how the experiences of pleasure and suffering at work occur, and what strategies are used by the employees to deal with the suffering, if there is any.

* Corresponding author:

antlogacarla@gmail.com (Carla Sabrina Antloga)

Published online at http://journal.sapub.org/ijap

Copyright (C) 2012 Scientific \& Academic Publishing. All Rights Reserved
The chosen enterprise for the study is a medium-sized company, and the investigation was performed qualitatively both to collect and to analyze the data. Preliminarily, the company was categorized, based on data such as its history and functioning, in addition to open interviews and structures questionnaires, both focused on the owners of the organization. After that, some employees from the administrative section were selected, conveniently, by inviting them to participate in the study. Four volunteers were presented, who participated of a group interview semi-structures.

The interview was based on two points "organization of work" and "feelings at work". It was analyzed descriptively, seeking data of the organization at work of this section. Then, categorical the matic content analysis was used[3].

This article is divided into four sections. The first topic encompasses the psychodynamics of work, organization of work and the experiences of pleasure and suffering; the second topic rescues the tools and the methodological stages used, going from the characterization of the company to the description of the subjects in the research and the group of tools and procedures adopted until the analysis of the data; the third topic considers the results of the development of the research; the fourth topic of the article presents the discussion of the received data and the conclusion of the article.

\subsection{The Human Being and Work}


Work is a significant and structuring activity for the human being. Studies about the prehistorical period confirm that there had already been organized forms of hunting and performing routine tasks[4]. It is evident that work is a peculiar and singular way used by human beings to fulfill, support economically and structure psychically. Thus, mentioning humanity means, consequently, to mention work.

Chronologically, a profile can be traced of the ways to perform work and how the modifications happened over the 20th century. The first system of production to be structured is considered to be the taylorism[4]. Based on the principles of ho mogeneity, vert icalization, frag mentation, mechanizati on and repeatability, this work system suppressed the intellectual activities and the knowhow, in a way that the emp loyee did not relate to his/her tasks.

Contemporary to the tayloris $m$, there is the ford is $m[4]$, based on similar principles, highlighting the value given to the serial production, the performance of the tasks also sectioned and repetitive, resulting in similar products and standard processes. Over this period there was a total control over the employees' movements. Their psychic events, when recognized, were $d$ ismis sed.

In the $60 \mathrm{~s}$, the binomial tayloris $\mathrm{m}$-fordis $\mathrm{m}$ started to decline[5]. The employees, who were before do minated and controlled, start to react in a consisted and organized way, questioning the pillars of capitalism. Individual and collective forms of action were manifested in different forms that ranged from absenteeism to partial strikes and "operation of zeal", employees' collective strategy that adopts a policy of extreme care and preservation of their work material, which leads to slowness and delay in the production. Related to capitalism, there was an economical shortage of the cycle of flexible accumulation, the pillar of the system. The form of the production in large scale, aiming a bigger consumption and bigger profit generation, was shaken[5]. In the early 70 s, there is a complete restructuring, however the capitalism, that was renewed, continues to be the prevailing system in the world[5].

From the reformulation of the capitalism, that happened as an attempt to recover the productive cycle, the toyotism is structured, or the Japanese model[5]. This model assumes the team work, bigger number of tasks in shorter time period, applied in a " lean" company, with a reduced staff and low costs. From this principle the processes of outs ourcing begin, in which the emp loyee earns to think for the company. This way, what it is seen today is a form of work that, in a certain way, revives the tayloris $\mathrm{m}[5]$. It cannot be ignored the fact that globalization brings along frenetic changes, that transform the environment proportionally. For complex questions concerning work, it is necessary to have fast, accurate solutions that keep the organizations and the employees in a fierce competition circuit.

With this view, the employee provided with the psychic structure and feelings, experiments the most different kinds of sensations and experiences. Broad questions arise: How does this subject face the adverse situations? What are the most frequent feelings, and what are the ways to deal with that? What does he/she think of the organizational occurrence that occupies a good deal of his/her life?

To think about the employees' well being is to think in the organizational effectiveness. Ferreira[6] points out this interrelationship when defending the necessity of a better work environment and an organization of work that privileges the inter individual characteristics of the employees, which becomes a work environment prone to productivity. In summary, if the employees possess well being in their work relationship inside the organization, they present a lower rate of sickness, therefore less absences; similarly, if they feel comfortable with their obligations and demands, it will reflect a greater autonomy, the level of job rotation decreases, the productivity increases and the customer service improves.

\subsection{Psychodynamics of Work, Organization of Work and Pleasure and Suffering Experiences}

The psychodynamics of work is an approach based on the psychoanalysis, and it seeks to clarify the relationship established between the individual and the work, characterized by the space where it occurs the mediation of ego fulfillment in the social field.

Organization of work is a term that surpasses the physical aspect of the employee's tasks. It is an intersubjective process, where interpersonal relationships and work relationships are involved, influencing the feeling relevant to this reality.

Mendes[7] deals with the organization of work as "an intersubjective process in which different subjects are found interacting with a certain reality, resulting in an own dynamics concerning their work situations as a place of production of psychic meanings and of construction of social re lations.

For this study, the operational definition of the organization of work is proposed, by analyzing the technical and dynamical point of $v$ iew [8-9].

The technical aspect is translated into the activity, into the processes and into the social-professional relationships and into the physical environment where the work is performed. On the other hand, the dynamics aspect is a result of the game of strengths between the employees in the sense of defining and negotiating the rules, creating team work, responsible for the ways of performing the work of a certain group.

An organization of work, to favor the employee's pleasure and the psychic health, must value the participation, the autonomy and the flexibility of the work process, factors that change or reduce the suffering[10]. It proposes that a flexible organization of work provides benefits for the employees' psychic health, whereas it promotes the integration, the globalization of the processes, methods and work tools, allowing, thus, that the tasks are noticed as significant. Furthermore, it stresses the importance of autonomy, of the use of technical and creative competences, 
and of the hierarchical relationships based on trust, cooperation and definition of rules by team work.

The pleasure is presented associated to the recognition and appreciation of the employee by the work organization, and the activities that have a beginning, middle and end. Besides that, the visualization of the production results, decentralization of decision and hierarchical flexibility also are highlighted, related to the pleasure. To the author, the pleasure results more from the sublimating investments than from the changing of the suffering itself. The suffering is presented associated to the division and standardization of tasks, to the underutilization of the technical potential and the creativity, to the hierarchical hardness, to the lack of participation in the decision and lack of professional appreciation, to the political interference, to the centralization of information, to the little professional growth perspective and to the individualism among co-workers.

Derrienic and Vézina[11] point to the big and growing number of "infra pathological" complaints, understood by labor doctors as psychic suffering originated probably from their profession. By analy zing four epidemiological studies concerning mental health and work, the authors conclude that data point to the confirmation of the idea that the psychic suffering at work, when it is not suppresses by defensive strategies, individual or collective, may have strong influence over the productivity and mental health. Concerning the productivity, the authors also observed the presence of demobilization, lack of commitment, and individualism; concerning the mental health, there is depression and neuroses. The consonance of the epidemiological results with the research carried out through the psychodynamics approach reinforces the link between the work organization and the psychic balance.

As it can be observed, the psychodynamics treats the issue of organization of work always relating it to the individual's feelings and developing the empirical relationships to help understand the employee's health conditions. In this sense, the issue of pleasure and suffering can be treated as consequences of the organization of work and as indicators of psychic health.

The first pieces of research about psychic suffering at work were carried out with civil construction workers, telephone operators and general working class[12]. The author showed, from these studies, that the reality at work influences positively and negatively the employees' psychic functions.

The continuation of the studies[1-2-13-14] points to several elements related to the organization of work that can cause suffering for the emp loyee.

In 1999, Mendes expanded the concepts of Dejours [7], by studying the pleasure-suffering as the constructing, to which three factors are related: appreciation, recognition and excessive wear. For the author, when the employee feels valued, he/she considers his/her work important for $\mathrm{him} /$ herself, for the company and for the society, in a mechanis $m$ of positive reinforcement for the self image, related to the pride of the work performed, to the professional fulfillment and to the feelings of helpfulness and productivity. The appreciation comes from the freedom and good relationship with bosses and co-workers, as well as from the space to build the collective work where there are margins for freedom and adjustment between the personal needs and tasks, The feeling of excessive wear is related to the tiring, unpleasant, repetitive, overwhelming activities that generates frustration, discouragement and dissatis faction.

The same author redefines and improves her concepts [15], and defends, then, as indicators of pleasure and suffering at work. As indicators of pleasure, there is the fulfillment and the freedom. Fulfillment is the feeling of reward, pride and identification with the work that meets the personal needs. Freedom is the feeling to be free to think, to organize and to talk about work.

As indicators of suffering, there is the excessive wear and the depreciation. Excessive wear is related to the feelings of discouragement, tiredness, anxiety, frustration, emotional tension, overload and stress at work. Depreciation is related to the feelings of insecurity when facing pressure to meet the demands of performance and productivity. In this study, these definitions will be used.

There are two ways through which the suffering can be driven, since its appearance: the subject can adopt an strategy of subjective mobilization or a strategy of defense. If these two strategies fail, sickness might be used in order to manifest this feeling.

The subjective manifestation is a process of pursuing the pleasure, when it cannot be experienced at work. In this process, the individual looks for a change of the situations that generate the suffering, making them, from this change, a source of pleasure.

The change of the suffering into pleasure passes through the recognition of work, and the recognition passes through the record of building the identity. The suffering may be seen as an element for the normality, since it is from this feeling that there is a confrontation of the imposition and pressures at work, leading to the healthy; there may be at work place, not unfolding into pathology. This is what Reicher-Brouard[16] defends when he claims that, through the recognitions concerning the quality of work, the suffering may be changed, leading the employee to search for new situations and challenges.

The concept of subjective mobilization was first worked by Dejours and Abdoucheli[2-17-18-19]. These researchers characterize the mobilization through the use of the employees' psychological resources along with the public space for the discussion about the work. The functioning of the subjective mobilization goes through the rescue of the sense of work from the re-framing of the suffering[20]. The meaning of work may be understood as the aspect of inter-relationship among the employee's subjectivity, the knowledge and the collective work. Subjectivity involves the relationship between the psychic and the social. It is how the employee makes sense of his/her work, when 
facing a certain reality. On the other hand, the knowledge, type of intelligence developed at work, helps the subject to regulate the prescribed and to develop a particular operative way in order to perform the work, many times overlapping the leadership's determinations and the organization's rules. The collective work involves cooperation, sympathy, trust among peers, being this collective built from the shared rules and from the commitment solutions.

About the collective work, some authors [20-21] state that this is created in a situation, involving specific people and specific rules, and exists regardless of the company's will. The rules that constitute the collective work, according to the authors, are not only technical, but also related to the relationships between people, having an ethical dimension that refers to the concept of fair-unfair, and to the values, besides relating also to the judgment of aesthetics and quality of work.

The studies about subjective mobilization have been more theoretical than empirical, but research is already in progress that aims to investigate how indicators of mobilization subjectivate the cooperation, the sympathy, the trust and the engaging in discussion of the group, with the goal to induce changes[21]. This research starts with the assumption that the consequences of the subjective mobilization leads the employee to an increase in motivation and in the ability to participate actively in collective discussions, aiming to modify the rules related to the task content and to the social-professional relationships that cause suffering.

Another strategy to cope with suffering is to use the defense. These are collective, and involve strategies to deny, avoid or reduce the suffering that is shared[14]. They are used when the organization of work does not favor the collective work, being based on the lack of cooperation and trust.

As a most used means of defense, Merlo and Mendes[22] identified the denial, that represents the denial of the other's and own suffering when the expression of this suffering if embarrassing or when it causes a subjective difficulty; the rationalization, that has its origin in the disassociation of the work process[23], and it is presented in the means of usage of rational justifications to cope with the conflicting situations; the individualism, when there is a naturalization of the context that generates the suffering, not existing the collective work; the passivity, expresses through the immobility when facing the impositions and the impossibilities to change the work reality, in a behavior of accommodation when facing the organization of work, using it to justify the no changes in the situations; the speeding of the rhythm at work; using of jokes while a task is performed; arriving earlier at work; following the guidelines or leave; creating exp ressions; getting away from the client/user; and, finally, the affective dullness.

The artificial psychic stability existing in some work contexts may disguise the psychic suffering, acquiring a pathological dimension. In the presence of this kind of stability the use of defensive strategies appear to be a positive resource, collaborating with the psychic balance and helping to adapt to the permanent situations of emotional distress.

Thus, it can be observed that the issues of pleasure and suffering are linked to a work "kind of" significant, and to a workplace that enables the understanding that the work is mean ingful. For Morin[24], work is meaningful when it is intrinsically satisfying. Looking for a meaningful work is part of the pursue of pleasure.

\section{Method}

The performance of this case study took place in a civil construction material company in Brasília-DF, and it was selected qualitative strategies both for analysis and collection of data. Here, this company will be referred as Delta, a fiction name to preserve the identity of the organization.

The company Delta has been in the market for 26 years, Since its foundation, it has belonged to several different societies, although the major partner is still the same. It was founded in December, 1978, with a store in the satellite city of Ceilândia-DF. Since then, 8 more stores were opened, until they got to a bigger store where nowadays it is located in the Sector of Industry and Supply - Setor de Indústria e Abastecimento (SIA).

As a consequence of long crisis periods, in May, 1999 the company filed for bankruptcy, negotiating their debts with suppliers. 50 employees were laid off from the store that existed, at the time, in the satellite city of Samambaia, which was closed. The 34 employees that were not laid off were moved to the store at SIA, where layoffs also happened.

The number of employees at the company, at the time of the collection of data, was 234 people, plus the 64 service providers, which are mostly drivers and deliverers. The average level of education was a high school degree, and the average age was 27 years old. The average period working at this company was from 5 months to 2 years.

There is not a Human Resources Department in the company, neither strategies of people management. These activities were performed by the manager supervisor, regarding the store and the warehouse. In the administrative department, the human resources management is performed by the financial/ad min is trative manager.

The company Delta is characterized for being a bold retail store, try ing to help as many clients as possible and, thus, generate a high inventory and capital turnover. It is not limited to help a specific class of clients, and it seeks to offer products at competitive prices, with a technical, personal, simple and straightforward service provision.

Delta's mission is to be a competitive and innovative company inside its market, meeting the needs of its consumers, providing them with satisfaction and well being, pursuing the professional and personal growth of all its employees. The goal of the company is to offer the clients the best options of the products characteristic of its segment, 
at fair prices, with convenience and comfort, and by doing so, making a profit that allows the maintenance and growth of the company and its emp loyees.

The main guidelines are: buying qualitatively at a low price, selling growing amounts, linked to the service provision, increasing the profit margins and reducing the costs and expenses. In this sense, the company is guided basically by the past evolution, the years of 2000 and 2001, of each variant (buying, selling, expenses, number of assistance) to determine the future goals, always attempting to grow in a way that overcomes the losses related to the economical variants (such as the inflation and interests), and the market growth, resulting in a real growth.

The origin of the financial resources comes only and exclusively from the buying and selling of products. The improvement in the service provision is, consequently, the only means to maximize the earnings. As far as improvement in the service provision, it is understood that the optimization of the processes of choice, buying, storage, organization, selling, assistance and delivery.

For the client, the official product of the company is the civil construction material. For the employees, the orientation given is that the official product is the "good service provided". The products sold at the company come from all over the country. In past moments, in 1996 and 1997, there was importation of tiles straight from Spain and Italy, and metals from Argentina. Nowadays, the company buy imported products with companies that have branches in Brazil.

The product outlet is exclusively through the process of sales, which can be self-service, when the client gets the products from the shelf and goes through the cashier; traditional service, when the client asks a sales assistant and the product is taken from the expedition service or the warehouse; and delivery, when the client specifies the address that he/she wants the material to be shipped to.

The feedback is not an official process, due to the informal relationship inside the company, It happens daily, through the follow-up of the managers and other people in charge, that are responsible for coordinating the operational tasks, assuring that there is no impediment for the emp loyees to perform their tasks.

In order to carry out the study, at first, there was a contact with the owner of the company to check the possibility to do so. The authorization was granted for the interview and the application of the questionnaire. It was allowed that the interview took place during the working hours, in the store itself, if it did not take more than one hour and a half.

Since the company direction allowed the interview to take place during working hours, it was set with the manager of the department the most convenient day and time for the interview. The company provided the training room, and during the interview the door was closed.

The collection of data was through the free observation, document analysis, open interviews, questionnaire about the company and collective interview with the employees mentioned above. The instruments, and the application are described below:

Free observations: The company routine, both at the store and administration, as well as the physical structure, opening and closing times, the relationship of the employees were observed freely. These observations occurred on the week when the interviews were performed, and during the normal working hours. These observations were analy zed qualitatively.

Document analysis: The documents provided by the company, such as a list of employees, bankruptcy notice published on the official journal, models of employees' warnings, company's chart and store layout were analyzed descriptively, since the amount was not enough for a content analysis. The documents were submitted to a descriptive qualitative analysis, the contents being registered related to the characterization of the company only concerning the presence or absence.

Open interviews: 4 (four) open interviews were performed with the owners of the company, 2 (two) with each of them. In theses interviews, it was intended to find information about the company history, its functioning, as well as its structure, areas of work, main crisis and changes.

Questionnaire about the organization: the questionnaire carried out with the owners consisted of 20 (twenty) questions, related to the company's characteristics, with the mission, values, input, and about the administration of human resources, also aiming to characterize the organization. This interview was handed to the owners and collected 1 (one) week later.

Semi-structured collective interview: the participants of the interview were selected randomly in the administrative department. The emp loyees were number on the list of employees provided by the company and after that 7 employees were drawn in the department, following a table of random numbers, All the people that were selected received phone calls from the researchers, inviting them for the collective interv iew that was going to take place at their workplace, during working hours, and that it would take around 1 hour. 4 employees of the administrative department attended the interview.

The semi-structured interview is centered on the person, and the interviewer must use techniques of reformu lation in order to collect the data[3]. This way, there are main points, but the questions that stem from these main points are elaborated according to the logic of the interviewed and to the interview process.

In this study, 2 main points guided the script of the interview.

The first point, referred to the organization of work, which contained questions about the activity, involving the content of tasks, process of work, pressures, control, working hours and breaks, besides the social-professional relationships with the co-workers and bosses. The main question of this point was "what do you do in a typical working day?", followed by "how are your relationships with your co-workers and bosses?".

The second point, referred to the feelings at work, which 
contained questions to investigate how the employees felt performing the work, interacting with the co-workers and with the bosses, and in case of having negative feelings, how they dealt with them. The main questions of this point were "how do you feel at work?" and "how do you deal with these feelings?".

To start the interview, the interviewer introduced and explained that the content of the interview was secret and explained the script briefly. It was clarified the need to have an audio recording for methodological matters. It was highlighted, at that moment, the volunteer character of the participation, confirming the will of the participants to be submitted to the interview. No employee gave up participating. The interview ran without interruptions and took 1 hour and 10 minutes.

The thematic categorical content analysis was performed[3]. To the the matic categorical analysis was used the criterion of recurrence of themes, that were submitted to a frequency counting. Recurrent themes are classified in specific categories, and then adjusted in general categories. The interview was submitted to the analysis of 2 (two) judges, that defined the specific categories, determined based on the predominant contents in the verbalizations found in the interviews.

\section{Results and Discussion}

Due to the data collection, the presentation of the results will be through the explanation of the organization of work and the pleasure-suffering of the employees.

\subsection{Organization of Work}

The administrative department of the company is in charge of all the bureaucratic part, also controlling the purchase of material and the personnel department. Although there are different functions, the employees of all the department are subjected to the same organization of work.

The working hours are divided in only one shift, that starts at $8 \mathrm{am}$ and it finishes at $6 \mathrm{pm}$ with 1 hour lunch break. However, they usually have to stay overtime. The emp loyees of this department do not earn overtime. Besides that, it is customary to take work to be done at home, since they do not have enough time to perform all the tasks in the company.

The control over the emp loyees is strict and intense, since they are close to the bosses, including physically, since they work on the same floor in the company. However, the intensity of this control is related mainly to the fact that all the employees in the administration have to report to several bosses, found in a same hierarchical position, what makes them nervous and confused. The rhythm at work is also intense, although it is not exactly fast: some tasks cannot be performed quickly, since they demand close attention, as in the case of evaluation of financial balance sheets. In the most striking aspect of this organization of work is the pressure exerted by all the leaders that are in constant contact with the employees determining difficult deadlines to be met, and emitting conflicting instructions, which is a mirror to the problems stressed in the communication, in the delegation and in the follow-up of the tasks and operations.

They claim that there is an excess of meetings, which harm even more the process of their tasks, They report an ambiguous behavior of the bosses, which is flexible only according to their own needs. They have a relatively far relationship with their co-workers.

\subsection{Pleasure and Suffering at Work}

The categories found in the interviews and the respective frequency are in the table 1 as follows.

Table 1. Summary of the cat egories of the interview

\begin{tabular}{|c|c|c|}
\hline \multirow{2}{*}{ Department } & Categories & Frequency \\
\hline \multirow{3}{*}{ Administration } & Relationship with the bosses & 35 \\
& Working hours & 19 \\
& Overload & 19 \\
& Necessity to enjoy the job & 11 \\
\hline
\end{tabular}

The details of the categories are presented in the following tables:

Table 2. Category Aof the interview in the administrative department

\section{Relationship with the bosses \\ (Frequen cy: 35)}

\section{De finition}

The bosses behave ambiguously concerning the employees' problems, being somet imes available and others not. Besides that, they ask the employeesto use creativity to perform the tasks, but do not accept when the work is done differently from the way it was prescribed, stopping the autonomy and making the employees feel revolted. There are many bosses to report to, many "egos" to fulfill, and they do not know who to answer first, feeling, because of that, uncomfortable, burdened, nervous, confused, divided. The employees state that they are not recognized and feel stressed, wom out and tired.

Table 3. Cat egory B of the interview with the administrative department

\section{Category B: Working Hours}

(Frequency: 19)

\section{Definition}

There is a dissat isfaction concerning the working hours, since it is flexible only according to the needs of the company. When an employee needs flexibility, he/she must bear the punishment, even the informal ones. The company also make the employees to perform non prescribed tasks, which generates an increase in the amount of work and makes it more difficult to perform the tasks. Besides that, there are complaints concerning the excessive amount of meetings. 
Table 4. Category $\mathrm{C}$ of the interview with the administrat ive department

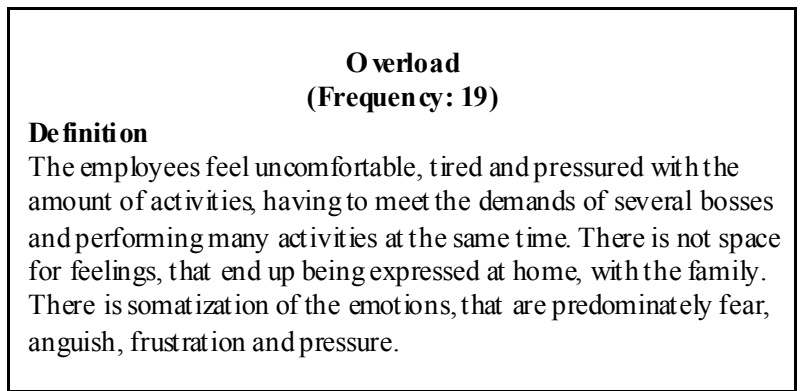

Table 5. Category D of the interview with the administrative department

Necessity to en joy the job
(Frequency: 11)

Category A, "relationship with the bosses", points to the perception of the company as it is centralized in the bosses, although they do not agree about the priority of the tasks. The categories B and C, "working hours" and "overload" indicate anexcessive wear of the employees, that feel the work routine to be heavy and extensive. Besides that, they do not notice any appreciation fro $m$ the boss es, and feel numb about their creativity.

Another relevant aspect of category A is the perception of double command, encouraged by the direct contact with the bosses. The fact to have many bosses makes it difficult to work in this department.

Category D, "necessity to enjoy the job", reveals an organization that seduces using the salary. The employees must enjoy the job because they have a job, and besides that because the salary is one of the best in the job market concerning civil construction material area. The feelings do not matter: the company pays well, and they remain with the lack of space to feel or even think.

In all the categories of this interview it can be observed suffering at work. In category $\mathrm{A}$, the suffering results from the perception of ambiguity in the behavior of the bosses, and the fact of not knowing who to obey, which provokes feelings of stress, tiredness and exhaustion. Furthermore, they do not feel any recognition from the bosses regarding the tasks they perform.

In category B the suffering appears related to the excess of work, meetings and the working hours, which is flexible only if it is convenient for the company.

Category $\mathrm{C}$ presents the employees' suffering also related to the excess of work and to the feeling of being exploited. The work makes them tired, afraid, anguished, frustrated and with a feeling of being pressured. Since there is no space for emotions, they end up somatizing what they feel.

In category $\mathrm{D}$ there is the perception that if there were feelings at work, there would be harm for the production. The employees are aware that they need to enjoy the job, both for the fact that they have a job and that they are well paid. The necessity to avoid feelings ends up generating discomfort.

\section{Conclusions}

In the last decade, it can be observed an expressive development in the administration of companies and the management of human resources in our country. However, there are organizations that still do not understand the importance of coherence in their admin istrative area and in the global adminis tration of the organization.

The company analyzed in this study presents a history of opening and closing down of stores, an aspect that shows instability of the company. It also shows difficulties in the administration of the resources. It is alarming the fact that a company cannot find its place in the market, having difficulties to establish limits and goals, and making itself excessively available to take risks[25]. When the instability appears to be momentary in the organization's history, it is understood as part of adaptation of the co mpany to the means. In the case of the company in question, the instability stands out all over its history. If a crisis stage generated excessive expenses for the organization, it can be concluded that a "permanent" crisis makes the administration much more difficult, both financially and concerning the energy and the effort spent in the process of admin is tering.

Concerning the categories resulting from the analysis of content, the first category, "relationship with the bosses" shows that the relationship with the emp loyees is a mbiguous, which may cause apprehension, anxiety, and consequently low motivation. It is essential that, in a work environment that intends to be healthy, there is transparency of information and clarity of roles. Otherwise, both the emp loyee and the company suffer the consequences of the distress promoted by the difficulty of communication.

The a mbiguity in the commands, and the relation like "two weights, two measures" also is presented in the category "working hours". It is stressed there, the exploitation of the emp loyee by the company. At first, the organization may be able to, with a policy of extreme pressure, have a higher productivity from the employee. However, over the time, this kind of strategy provokes excessive wear and stress, harming the performance, increasing the turnover and the dissatis faction with the organization.

It is known that many organizations go through difficult moments, where a bigger effort is demanded from all the collaborators. This effort, however, needs to be appreciated and rewarded. If it is taken as basis Maslow and $h$ is pyramids of necessities, it can be concluded that the people do not move only to satisfy their physiological and safety needs, but also the social, where it is included the need to know they are important. The company in question certainly would benefit in productivity if they favoured the effort and the work of 
their collaborators.

The excessive amount of meetings, that appears in category B, may be related to the lack of communication, or to the ambiguous communication mentioned by the employees. Evidently, the more time it is spent in meetings, the less it is produced. Excess of meetings to attempt to have a bigger control both over the employees and over the processes may lead to a perception of useless meetings, Even inside the basic theories of perception it is found that when an institution is excessively exposed to stimulus, there is a trend to "tiredness", and the reply does not occur as expected.

The fear, anguish, frustration and pressure content in the category "overload", lead the employees to distress, and consequently to the reduction of work efficiency and to suffering. The amount of negative feelings is so big that the employees, in a defensive position against the suffering, they start to feel obligated to enjoy the job, as it is shown on category D, "necessity to enjoy the job". To continue working, in spite of everything that they feel that is bad and frustrating, the emp loyees argue that they must find positive the fact of having a job. It is worrying, however, the fact of defenses, when used for a long time, to finish or fail, or turning suffering into psychological or physical diseases, or even psychosomatics.

Therefore it can be concluded that the company, in spite of the several attempts to control as much as possible both the employees and the processes performed by them, has had losses that may not justify the excessive control. Evidently, the processes in the organization must be reviewed specially the ones that concern the human resources: the creation of a administrative department of human resources is urgent, so the processes of hiring, training and evaluation of performance development can be established harmonically, allowing that the employees work, and do not waste time and energy worrying with unnecessary matters. This strategy can, in medium term, pro mote the pleasure at work.

Another point to be stressed is the excess of mistrust: the employees seem to have to explain everything all the time, not having a relationships of reciprocity: they must trust the company, but the company does not trust them. As the studies of pleasure and suffering at work indicate, the appreciation is one of the items related to the pleasure at work. Without that, both the organization and the employees tend not to enjoy optimally their potential of realization.

It is recommended in previous studies that other involved variants such as: the bosses' policy, problematics of family companies concerning pleasure and suffering and still other is sues that might interfere in the experiences of pleasure and suffering of employees.

\section{ACKNOWLEDGEMENTS}

The authors wish to acknowledge their families, the participants that made this research possible and de groups of research ErgoPublic and Laboratório de Psicodinâmica e
Clín ica do Trabalho.

\section{REFERENCES}

[1] C. Dejours, 1987, Plaisir et souffrance dans lês travail, Paris: Centre National de la Recherche Scientifique.

[2] C. Dejours, 1999, Conferências Brasileiras: identidade, reconhecimento e transgressão no trabalho, (ACF Reis, Trad.). São Paulo: Fundap, EAES/ FGV.

[3] L. Bardin, 1977, Análise de conteúdo, Lisboa: Edições 70.

[4] R Antunes, 1998, Adeus ao trabalho? Ensaio sobre as metamorfoses e a centralidade do mundo do trabalho, Campinas: Cortez.

[5] R. Antunes, 2000, Os sentidos do trabalho: ensaio sobre a afirmação e a negação do trabalho, São Paulo: Boitempo Editorial.

[6] M. C. Ferreira, 2006, Qualidade de Vida no Trabalho, In: A. D. Cattani, and L. Holzmann (Orgs.). Dicionário de Trabalho e Tecnolo gia. Porto Alegre: Editora da UFRGS.

[7] A. M. Mendes, 1999, Valores e vivências de prazer e sofrimento no contexto organizacional, Tese (doutorado). Universidade de Brasília, Brasília.

[8] M. C. Ferreira, and A. M. Mendes, 2001, "Só de pensar em trabalhar, já fico de mau humor": atividade de atendimento ao público e prazer-sofrimento no trabalho. Estudos de Psicologia, v. 6, n. 1, p. 93-104.

[9] M.C. Ferreira, and A. M. Mendes, 2003, Trabalho e riscos de adoecimento: $\mathrm{O}$ caso dos auditores fiscais da Previdência Social Brasileira, Brasília DF: Edições Ler, Pensar, Agir (LPA), p. 33-59.

[10] A. M. Mendes, 2007, Da psicodinâmica à psicopatologia do trabalho, In: A. M. Mendes (Org.). Psicodinâmica do trabalho: teoria, método, pesquisas.1. ed. São Paulo: Casa do Psicólogo.

[11] F. Derrienic, and M. Vézina, 2000, Organisation du travail et santé mentale: approches épidemiologiques, Revue Internationale de Psychopathologie et de Psychodynamique du travail, v. 5 , p. $07-22$.

[12] C. Dejours, 1987, A Loucura do Trabalho: estudo de psicopatologia do trabalho, São Paulo: Cortez.

[13] C. Dejours, 1990, Inteligence ouviére et organisation du travail (cinquième partie). In : H. S. Hirata (Ed.), Autor du "modéle" japonais: automatisation, nouvelles formes d'organisation de travail. Paris: Dynamiques d'Enterprises l'Harmattam.

[14] C. Dejours, 1993, Travail: usure mental, Paris: Bayard Edition.

[15] A. M. Mendes, 2004, Escala de Indicadores de Prazer e Sofrimento no Trabalho. Revista Mente Social, v. 10, n. 1, p. 10-22.

[16] V. Reicher-Bouard, 1997, Souffrance et puvoir dans le travail. La complexe dynamique de la reconnaissance. In : Conservatories Nátional dês Arts et Métiérs (Org.). Acts: 
Colloque International de Psycodynamique et Psychopathologie du travail. Tome II, p. 187 - 199). Paris: CNAM.

[17] C. Dejours, and E. Abdoucheli, E., 1990, Intinéraire théorique en psychop athologie du travail. Revue Preven ir, França, v. 20, p. 21-38.

[18] C. Dejours, 1992, O sofrimento humano nas organizações. In: S. L. O. Torres (Org.). O indivíduo na organização: dimensões esquecidas. São Paulo: Atlas.

[19] C. Dejours, 1999, A banalização da injustiça social (LA Monjardim, Trad.). Rio de Janeiro: Editora FGV.

[20] A. M. Mendes, and L. K. R. Araújo, 2011, A psicodinâmica do trabalho bancário. In: V. B. Rego (Org.). Adoecimento psíquico no trabalho bancário: da prestação de serviços à (de)pressão por vendas. Brasília: Ex Libris.

[21] A. M. Mendes, and C. F. Morrone, 2002, Vivências de prazer-sofrimento e saúde psíquica no trabalho: trajetória conceitual e empírica. In: A. M. Mendes, L. O. Borges, and M. C. Ferreira (Orgs.). Trabalho em transição, Saúde em risco. Brasília: Editora UnB.

[22] A. R. C. Merlo, and A. M.Mendes, 2009, Perspectivas do uso da psicodinâmica do trabalho no Brasil: teoria, pesquisa e ação. Cadernos de Psicologia Social do Trabalho, v. 12, n. 2 , p. $141-156$

[23] A. M.Mendes, 1995, Os novos paradigmas de or ganização do trabalho: implicações na saúde mental dos trabalhadores, Revista Brasileira de Saúde Ocupacional, v. 23 n.85/86, p. 55-60.

[24] E. A. Morin, 2002, Sentidos do trabalho. In: T. Wood Jr. (Org.). Gestão empresarial: o fator humano. São Paulo: Atlas.

[25] T. Wood Jr., 2002, Executivos neuróticos, empresas nervosas. São Paulo: Negócio Editora. 